\title{
Short term results of balloon pulmonary valvuloplasty in children: a single centre study over a period of 42 months
}

\author{
Sunethra Irugal Bandara ${ }^{1}$, Sinnathurai Narenthiran ${ }^{2}$, Wijeyasingam Santharaj ${ }^{2}$ Kanapathipillai \\ Rajakanthan $^{3}$, Duminda Samarasinghe ${ }^{1}$, Shehan Perera ${ }^{1}$, Upul Senarath ${ }^{4}$
}

Sri Lanka Journal of Child Health, 2011; 40: 13-15

(Key words: balloon pulmonary valvuloplasty; BPV; pulmonary stenosis; children)

\begin{abstract}
Objectives: To evaluate the efficacy and safety of balloon pulmonary valvuloplasty (BPV) in children.

Design, setting and method: This is a retrospective review of 101 consecutive patients with pulmonary stenosis who underwent BPV at the Lady Ridgeway Hospital for Children over a period of 42 months. Four patients were excluded as they had complex cardiac problems. Data was obtained from Excel based cardiac catheterization reports in the Department of Paediatric Cardiology. Reduction of pressure gradient across pulmonary valve to less than $25 \mathrm{mmHg}$ was defined as a successful procedure.
\end{abstract}

Results: Ninety seven BPVs were performed in 94 patients. The mean age, bodyweight and height were 19 months, $9.5 \mathrm{~kg}$ and $80 \mathrm{~cm}$ respectively. Sex distribution was equal. The mean of the balloon to pulmonary annular ratio was 108\% (range 50-150\%). After the BPV, mean peak to peak pressure gradient across the pulmonary valve dropped from $70 \pm 29$ $\mathrm{mmHg}$ to $24.7 \pm 16.8 \mathrm{mmHg}$. Overall success rate was $55.7 \%$. Mortality was $3.1 \%$. Major complications were haemopericardium $(4.1 \%)$, bradycardia (2\%) endocardial damage (1\%) and pulmonary oedema (1\%). The correlation between pulmonary annulus on echocardiography and angiography was significant $(\mathrm{p}<0.01)$.

${ }^{1}$ Department of Paediatric Cardiology, Lady
Ridgeway Hospital for Children, Colombo,
${ }^{2}$ Department of Cardiology, National Hospital,
Colombo, ${ }^{3}$ Department of Cardiology, Teaching
Hospital, Colombo North, Ragama, ${ }^{4}$ Department of
Community Medicine, University of Colombo

(Received on 3 April 2010. Accepted on 20 May 2010)

\section{Introduction}

Congenital pulmonary valve stenosis (PS) has been found in $8-10 \%$ of patients with congenital heart diseases ${ }^{1}$. Right ventricular dysfunction, fibrosis or infarction may be seen in patients with severe $\mathrm{PS}^{1-3}$. Pulmonary valvuloplasty is the first option in the management of congenital $\mathrm{PS}^{4-8}$. The short term results of pulmonary valvuloplasty in children with typical PS have been excellent ${ }^{9-13}$.

Complications are lower in children and adults than in infants and neonates. Mortality and morbidity among neonates were $3 \%$ and $10 \%$ respectively ${ }^{14}$.

Studies on balloon pulmonary valvuloplasty (BPV) have not been conducted previously in Sri Lanka.

\section{Objectives}

To evaluate efficacy and safety of balloon pulmonary valvuloplasty in children

\section{Method}

This is a retrospective study of 101 consecutive patients with pulmonary stenosis who underwent BPV at the Lady Ridgeway Hospital for Children (LRHC) over a period of 42 months from $1^{\text {st }}$ January 2006 to $30^{\text {th }}$ June 2009. Four were excluded as they had complex cardiac problems with pulmonary stenosis. Well designed and maintained Excel based cardiac catheterization reports in this unit were reviewed and the data was collected into a data extraction Excel sheet.

\section{Results}

Immediate and short term outcomes of BPV were reviewed. There were 94 children aged 2 days to 12 years (mean 19 months) who underwent BPV. Categorization of cases is shown in Table 1. 
Table 1

Categorization of cases

\begin{tabular}{|lc|c|}
\hline \multicolumn{2}{|c|}{ Category } & Number (\%) \\
\hline Age & $<1 \mathrm{yr}$ & $35(36)$ \\
& $1-3 \mathrm{yrs}$ & $23(24)$ \\
& $3-<5 \mathrm{yrs}$ & $14(14)$ \\
& $\geq 5 \mathrm{yrs}$ & $25(26)$ \\
\hline Sex & Male & $49(51)$ \\
& Female & $48(49)$ \\
\hline Weight & $<5 \mathrm{~kg}$ & $12(12.4)$ \\
& $5-10 \mathrm{~kg}$ & $39(40.2)$ \\
& $10-20 \mathrm{~kg}$ & $35(36.0)$ \\
& $>20 \mathrm{~kg}$ & $11(11.4)$ \\
\hline Height & $83 \pm 24.5 \mathrm{~cm}$ \\
\hline Pressure gradient before & \\
pulmonary valvuloplasty(on Echo) & \\
& $<50 \mathrm{mmHg}$ & $02(02)$ \\
$50-74 \mathrm{mmHg}$ & $29(30)$ \\
$75-99 \mathrm{mmHg}$ & $34(35)$ \\
& $>100 \mathrm{mmHg}$ & $32(31)$ \\
\hline
\end{tabular}

The pulmonary annular size on echocardiography and angiography were $12 \pm 3.8 \mathrm{~mm}$ and $12.53 \pm 4 \mathrm{~mm}$ respectively. The correlation between these two was significant at 0.01 level as shown in Figure 1.

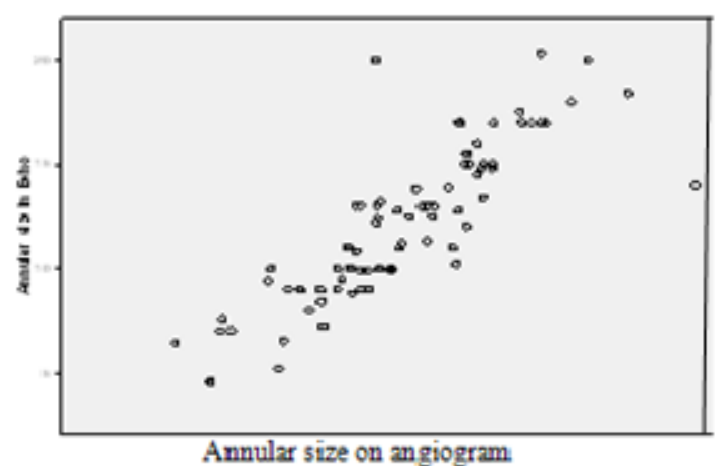

Figure 1: Correlation between pulmonary annulus on echocardiography $(r=0.847)$ and angiogram $(r=0.847)$

Peak-to-peak gradient dropped from $70.50 \pm 29.25$ to $24.7 \pm 16.8 \mathrm{mmHg}$ (Paired sample statistics).Three patients underwent repeat BPV. Seven cases were abandoned due to several reasons (mild pulmonary stenosis on catheterization, infundibular pulmonary stenosis and unavailability of suitable balloons). Fifty four patients were successful as residual pressure gradient $(\mathrm{PG})$ after BPV was $<25 \mathrm{mmHg}(60 \%)$. The mean balloon/pulmonary annular ratio was $108 \%$ (range 47-151\%) excluding the failed and abandoned patients (Table 2).
Table 2

Mean balloon/pulmonary annulus ratio

\begin{tabular}{|c|c|}
\hline $\begin{array}{c}\text { Pulmonary annulus / } \\
\text { Balloon ratio x100 }\end{array}$ & Number (\%) \\
\hline$<99$ & $09(11)$ \\
\hline $100-119$ & $53(64)$ \\
\hline $120-139$ & $19(23)$ \\
\hline$\geq 140$ & $02(02)$ \\
\hline Total & $\mathbf{8 3}(\mathbf{1 0 0})$ \\
\hline
\end{tabular}

\section{Failures}

The procedure was unsuccessful in 36 patients, 24 of whom had residual pressure gradient between 26-50 $\mathrm{mmHg}(24.7 \%)$ and only five patients had gradient of $>50 \mathrm{mmHg}$. The procedure failed in 7 with critical pulmonary stenosis (unable to cross the pulmonary valve in 6 , endocardial damage in one). However the numbers are inadequate for statistical analysis and the characteristics of the failures are shown in Table 3.

Table 3

Characteristics of the failures

\begin{tabular}{|c|c|}
\hline Characteristic & $\begin{array}{c}\text { Failure rate } \\
\text { Number (\%) }\end{array}$ \\
\hline Age $\quad<1 \mathrm{yr}$ & $17(49)$ \\
$1-<3 \mathrm{yrs}$ & $07(30)$ \\
$3-<5 \mathrm{yrs}$ & $01(07)$ \\
$\geq 5 \mathrm{yrs}$ & $11(44)$ \\
\hline Weight $<5 \mathrm{~kg}$ & $08(66)$ \\
$5-<10 \mathrm{~kg}$ & $13(33)$ \\
$10-<20 \mathrm{~kg}$ & $08(23)$ \\
$\geq 20 \mathrm{~kg}$ & $07(63)$ \\
\hline
\end{tabular}

Failure of crossing the pulmonary valve was seen in 2 neonates and 4 infants less than 6 months with critical pulmonary stenosis, two expired, one underwent repeat BPV and three were referred for surgery.

Severe residual stenosis ( $\mathrm{PG}>50 \mathrm{mmHg}$ ) was seen in infants with hypoplastic pulmonary annulus (2) and severely dysplastic pulmonary valves (3). They were referred for surgery. There were 3 deaths in this cohort. Complications of BPV are shown in Table 4.

Table 4

Complications of BPV

\begin{tabular}{|l|c|}
\hline \multicolumn{1}{|c|}{ Complications } & Number (\%) \\
\hline Death & $03(3.1)$ \\
\hline Haemopericardium & $04(4.1)$ \\
\hline Endocardial staining & $01(1.0)$ \\
\hline Bradycardia & $03(3.1)$ \\
\hline Pulmonary oedema & $01(1.0)$ \\
\hline
\end{tabular}




\section{Discussion}

In a newly established and only paediatric cardiology unit in Sri Lanka, a significant number of patients with moderate to severe pulmonary stenosis underwent BPV over a short period in spite of having limited resources and a new staff with minimal prior experience. The transpulmonary gradient dropped from $70.50 \pm 29.25 \mathrm{mmHg}$ to $24.7 \pm 16.8 \mathrm{mmHg}$ after the BPV. It is comparable with the other studies ${ }^{10,11}$.

The overall success rate was $55.7 \%$. In this study, procedure failure was mainly due to an inability to cross the severely stenotic valve. The same pattern was reported in other studies and this was overcome by the availability of new instruments. In addition, the experience of staff increased over time. However, the success rate is lower than in the centres with latest facilities which can achieve dilatation in 90$100 \%$ patients ${ }^{1}$. Early studies have shown the higher mortality and morbidity in neonates and infants ${ }^{14}$. The mortality rate in our series was $3.1 \%$ which is similar to some centres ${ }^{14}$. As seen in other studies, complications were common in neonates and infants ${ }^{14}$.

A limitation of this study is that data was obtained from the service records which were not specifically designed for this research.

\section{Conclusions}

- Overall success rate of BPV was $55.7 \%$.

- Mortality rate was $3.1 \%$.

- Major complications were haemopericardium, bradycardia, endocardial damage and pulmonary oedema.

- Correlation between pulmonary annulus on echocardiography and angiography was significant $(\mathrm{p}<0.01)$.

\section{References}

1. Allen HD, Moss AJ. Moss and Adams' Heart Disease in Infants, Children and Adolescents: including the Fetus and Young Adult. 7th ed. 2008, Philadelphia; London: Lippincott Williams \& Wilkins. 2 v, xxviii; 836: 844.

2. Garson A, Bricker JT, Fisher DJ, Neish SR. The Science and Practice of Paediatric Cardiology $2^{\text {nd }}$ ed.1998Williams \& Wilkins; ii: 1225.
3. Rao PS, Galal O, Patnana M, Buck SH, Wilson AD. Balloon Pulmonary Valvuloplasty in Children. J Invasive Cardiology 2005; 17(6): 318-22.

4. Rubio-Alvarez V, Limen-Lason R, Sonj J. Valvotomies intracardiacas por medio de u cateter. Arch Inst Cordiol Mexico 1952; 23:183.

5. Rubio V, Limon-Las on R. Treatment of pulmonary valvular stenosis and tricuspid stenosis using a modified catheter. $2^{\text {nd }}$ World Congress of Cardiology, Washinton, DC, Program Abstract, 1954; 11:205.

6. Semb BKH, Tijonneland S. Stake G et al."Balloon valvotomy" of congenital pulmonary valve stenosis with tricuspid valve insufficiency. Cardiovasc Radiol 1979; 2:239.

7. Kan JS. White RJ. Jr. Mitchell SE. Gardner TJ. Percutaneous balloon valvupoplasty; a new method for treating congenital pulmonary valve stenosis. New Engl Journal of Med 1982; 307:540-2.

8. Gruentzig AR, Senning A, Siegothaler WE. Nonoperative dilatation of coronary artery stenosis: Percutaneous transluminal coronary angioplasty. New Engl J Med 1979; 301:61-8.

9. O'Connor BK, Beekman RH, Lindauer A, et al. Intermediate-term outcome after balloon pulmonary valvuloplasty: Comparison with matched surgical control group. J Am Coll Cardiology 1992:20:16973.

10. Rao PS, Galal O, Patnana M, et al. Results of threeto-ten-year follow-up of balloon dilatation of the pulmonary valve. Heart 1998; 80:591-5.

11. Masura J, Burch M, Deanfield JE, et al. Five year follow-up after balloon pulmonary valvuloplasty. $J$ Am Coll Cardiol 1993; 21:132-3.

12. Rao PS. Further observations on the role of balloon size on the short-term and intermediate-term results of balloon pulmonary valvuloplasty. Br Heart $J$ 1988; 60:507-11.

13. Jelena M.E. Congenital Pulmonary Stenosis a Restrospective study of 24 cases seen between 1990-1999. Journal of Veterinary Cardiology 2001; 3 (2): 13-19.

14. Stanger P,Cassidy SC,Girod DA,et al.Balloon pulmonary valvuloplasty: Results of the valvuloplasty and angiography of congenital anomalies registry. Amer J Cardiology 1990; 65:775-83. 